\title{
A new genus and species of tarsonemid mite (Acari: Tarsonemidae) from Brazil
}

\author{
ANTONIO C. LOFEGO ${ }^{1} * \&$ REINALDO J.F. FERES ${ }^{2}$ \\ ${ }^{1}$ UNORP-Centro Universitário do Norte Paulista, Rua Ipiranga 3460, 15020-040, São José do Rio Preto, São \\ Paulo, Brazil \\ ${ }^{2}$ Departamento de Zoologia e Botânica, UNESP-Universidade Estadual Paulista, Rua Cristóvão Colombo, \\ 2265, Jardim Nazareth, 15054-000, São José do Rio Preto, São Paulo, Brazil \\ *Corresponding author.
}

\begin{abstract}
Biscutulumnemus neotropicus gen. nov., sp. nov. (Tarsonemidae: Tarsoneminae: Tarsonemini) is described from adult female and male mites, collected on Croton floribundus Spreng., from São José do Rio Preto, State of São Paulo, Brazil. This new genus resembles members of Dendroptus and Tarsonemus, but male mites have two triangular shields anterolaterally to the prodorsal shield and the sejugal apodeme is absent. In addition, Biscutulumnemus differs from Dendroptus by the presence of femoral seta $l$ " and tibial solenidion $\phi 1$ and the presence of a vestigial apodeme I on female mites. Unlike Tarsonemus, Biscutulumnemus has a beaklike gnathosomal capsule, a round flange on leg IV of male mites, and stigmata very close to $v 1$ on the prodorsal shield of female mites.
\end{abstract}

Key words: Tarsonemoidea, Tarsoneminae, new species, taxonomy, Biscutulumnemus, neotropicus

\section{Introduction}

Tarsonemid mites vary greatly in their morphology, biology and ecology. Consequently, they exhibit a significant diversity of species. However many of them are not known to science, especially from the tropical regions, where the number of described species is considerably smaller than in temperate regions (Lin \& Zhang 2002). A new genus and new species, collected in the state of São Paulo located in the southeastern region of Brazil on Croton floribundus Spreng, is described and illustrated. The weather in this region is of the Cwa-Aw of Köppen type with two distinct seasons: the rainy season, that ranges from October to March, and the dry season, that occurs from April to September, the latter of which constitutes only $15 \%$ of the annual precipitation (about 1,200 mm), with an annual 